Notre Dame Law School

NDLScholarship

Journal Articles

Publications

2009

\title{
The Limitations of Majoritarian Land Assembly
}

Daniel B. Kelly

Notre Dame Law School, daniel.kelly@nd.edu

Follow this and additional works at: https://scholarship.law.nd.edu/law_faculty_scholarship

Part of the Other Law Commons

\section{Recommended Citation}

Daniel B. Kelly, The Limitations of Majoritarian Land Assembly, 122 Harv. L. Rev. F. 7 (2009-2011).

Available at: https://scholarship.law.nd.edu/law_faculty_scholarship/664

This Response or Comment is brought to you for free and open access by the Publications at NDLScholarship. It has been accepted for inclusion in

Journal Articles by an authorized administrator of NDLScholarship. For more information, please contact lawdr@nd.edu. 


\title{
THE LIMITATIONS OF MAJORITARIAN LAND ASSEMBLY
}

\author{
Daniel B. Kelly*
}

Responding to Michael Heller \& Rick Hills, Land Assembly Districts, I 2 I HARV. L. REV. I465 (2008).

In Land Assembly Districts, Professors Michael Heller and Rick Hills attempt to solve a seemingly intractable problem: how is it possible to overcome the strategic holdouts that sometimes prevent socially desirable assemblies while ensuring that these assemblies are, in fact, desirable? Private assembly relies on consensual exchange and is thus generally welfare-enhancing. But private assembly may lead to holdouts and underassembly. Eminent domain avoids the holdout problem. But eminent domain may lead to "inefficient overassembly" or "wasteful underassembly." fare advantage of private assembly with the assembly advantage of eminent domain by retrofitting neighborhoods with a novel property rights arrangement, a Land Assembly District ("LAD").

A LAD is a district of property owners that has "the power, by a majority vote, to approve or disapprove the sale of the[ir] neighborhood to a developer or municipality seeking to consolidate the land into a single parcel." 2 Voting rights within the LAD are allocated in proportion to each owner's share of land within the district. With majority approval, the developer or municipality ("the assembler") obtains title to the entire district, and owners receive their proportional percentage of the bargained-for sale price. Any owner may "opt out," but the LAD is entitled to condemn an opt-out's parcel in exchange for just compensation (that is, the fair market value of the land). Without majority approval, owners retain their property, and neither the assembler nor the LAD is permitted to use eminent domain. ${ }^{3}$ The authors claim that, by permitting owners and assemblers to bargain over the sale price and by allowing owners to approve assemblies without

* Terence M. Considine Research Fellow in Law and Economics and Lecturer on Law, Harvard Law School. J.D., Harvard Law School; B.A., University of Notre Dame (dkelly@law. harvard.edu). I am grateful to Robert Ellickson, Tracey Meares, Steven Shavell, and Henry Smith for helpful comments and to the John M. Olin Center for Law, Economics, and Business at Harvard Law School for research support.

1 Michael Heller \& Rick Hills, Land Assembly Districts, I2 I HARV. L. REV. I465, I468 (2008). (emphasis omitted).

2 Id. at 1469.

3 See generally id. at 1469-7o (describing a LAD). 
unanimous consent, LADs are generally superior to both eminent domain and private assembly. ${ }^{4}$

In this Article, I raise a number of concerns regarding LADs in particular and majoritarian land assembly in general. I contend that, as a matter of social welfare, whether LADs are superior to eminent domain or private assembly is ambiguous. In Part I, I argue that LADs are not necessarily superior to eminent domain. The possibility of heterogeneity among existing owners' valuations means that LADs entail a risk of both too much and too little assembly. In Part II, I maintain that LADs are not necessarily superior to private assembly. By allowing existing owners to bargain over a project's assembly value, LADs increase developer costs and may lead to bilateral monopolies. In Part III, I suggest that, because they ultimately rely to a significant extent on judicial expertise and not just neighborhood selfgovernance, LADs also may not offer an administrability advantage over either eminent domain or private assembly. I conclude by noting that, despite these concerns, LADs constitute a creative proposal worthy of consideration.

\section{MAJority VOTING AND Heterogeneity}

LADs rely on majority voting and thus permit existing owners to approve an assembly without unanimous consent. In this way, LADs attempt to give developers, as well as owners, the ability to overcome holdouts - the primary benefit of eminent domain. Yet land assembly through majority voting also entails a cost. Specifically, because of the possibility of heterogeneity among owners' valuations, majority voting may cause LADs to approve socially undesirable assemblies (the problem of overassembly) and disapprove socially desirable ones (the problem of underassembly).

Consider an example. Five homeowners each own a parcel of the same size in the same neighborhood. Although each of the parcels has a fair market value of $\$ 9$, the owners value their properties differently. Owner I values her parcel at $\$ 10$, slightly above fair market value. Owners 2 and 3 value their parcels at \$I2, thirty-three percent above fair market value. Owners 4 and 5 value their parcels at $\$ \mathrm{I} 8$, two times fair market value. A developer values the parcels, as assembled, at $\$ 65$. Assume, for analytical clarity, that the valuations of the owners and the developer are observable and that the assembly does not involve any spillover effects.

\footnotetext{
4 See id. at I470 (arguing that LADS make eminent domain "unnecessary" for assembling fragmented land); $i d$. at $\mathbf{1} 474$ (asserting that "the rarity of the voluntary approach suggests its limits").
} 
If the developer seeks to assemble the land, what is the optimal result from a social perspective? I assume that an assembly is socially desirable if the assembler values the parcel more than the existing owners and socially undesirable if the existing owners value the parcel more than the assembler. Here, the existing owners value their properties at $\$ 70(\$ 10+\$ I 2+\$ I 2+\$ I 8+\$ I 8)$, whereas the developer values the properties at $\$ 65$. Because the existing owners value the parcel more than the assembler (that is, because an assembly would result in a loss of $\$ 5$ ), the assembly would be socially undesirable. The optimal result, therefore, is for the assembly not to occur.

Allowing the government to use eminent domain on behalf of the developer leads to this optimal result. A beneficent government, observing the owners' valuations, would exercise eminent domain if and only if the developer valued the land more than the existing owners. In this example, the developer values the land at $\$ 65$ and the existing owners value the land at $\$ 70$, so the government would not take the land.

Using a LAD, however, the developer could make an offer slightly above the median owner's valuation, say $\$$ I 2.20 per parcel. The developer is willing to make this offer because her valuation of the land, $\$ 65$, is higher than $\$ 6$ I (that is, $\$ \mathbf{I} 2.20 \times 5$ ), the sale price if the LAD approved the assembly. Owner I would accept the offer because $\$ 12.20$ is greater than $\$ 1$. O Owners 2 and 3 also would accept because $\$ 12.20$ is greater than $\$_{12}$. Owners 4 and 5 would reject the offer because $\$$ I 2.20 is less than $\$_{1} 8$. Nevertheless, the assembly would take place because three of the five existing owners, a majority, would have approved the sale. Here, because the median, $\$ \perp 2$, is below the mean, $\$$ I 4 (that is, $\$ 70 / 5$ ), the developer can offer just above the median and obtain all the land, even though the developer's offer, $\$ 6 \mathrm{I}$, is less than the total value of the parcels to the owners, $\$ 70$. There is thus a risk, due to heterogeneity, that LADs will approve assemblies that are socially undesirable.

Now suppose that Owner 3 , the median voter, values her parcel at $\$ 18$ (rather than $\$ \mathrm{I}_{2}$ ). The existing owners, therefore, value their properties at $\$ 76(\$ \mathrm{IO}+\$ \mathrm{I} 2+\$ \mathrm{I} 8+\$ \mathrm{I} 8+\$ \mathrm{I} 8)$. Under these circumstances, an assembly would be socially desirable whenever the developer values the land more than $\$ 76$ and socially undesirable whenever the developer values the land less than $\$ 76$. Consequently, the government, using eminent domain, would assemble the property if and only if the developer valued the property more than $\$ 76$.

By contrast, to assemble these properties using a LAD, the developer would need to make an offer slightly above the median owner's valuation, say $\$ 18.20$ per parcel, for a total purchase price of $\$ 9 \mathrm{I}$ (that is, $\$$ I $8.20 \times 5$ ). If a developer made an offer of $\$ 85$ (or $\$$ I 7 per parcel), a majority of the owners (Owners 3, 4, and 5) would vote against the assembly even though the offer, $\$ 85$, is greater than the owners' valua- 
tions, $\$ 76$. In fact, because of heterogeneity, any developer who valued the property more than $\$ 76$ but less than $\$ 90$ could not assemble the properties using a LAD even though such an assembly would be desirable. Here, because the median, $\$ \mathrm{I} 8$, is above the mean, $\$ \mathrm{I} 5.20$ (that is, $\$ 76 / 5)$, the developer must offer at least the median to obtain all the land, but the total offer required, $\$ 90$, would then be greater than the total value of the parcels to the owners, $\$ 76$. As a result, heterogeneity also means that LADs may disapprove certain assemblies that are socially desirable.

Overall, the problem with land assembly by majority voting is that the assembler is only concerned with the valuation of the median owner. But, because of heterogeneity among the owners' valuations, the median owner's valuation can be above or below the owners' average valuation. If the median is below the mean (because owners in the upper half of a distribution place values on their land that are particularly high relative to the median), then there is a risk of overassembly: the assembler can offer the median and obtain all the land, even though the offer is less than the total value of the parcels to the owners. If the median is above the mean (because owners in the upper half of the distribution place values on their land that are particularly low relative to the median), then there is a risk of underassembly: the assembler must offer at least the median to obtain all the land, but this offer is greater than the total value of the parcels to the owners. Thus, if there is heterogeneity among valuations, majority voting may lead to undesirable outcomes. ${ }^{5}$

\footnotetext{
5 Cf. Yoram Barzel \& Tim R. Sass, The Allocation of Resouvces by Voting, I05 Q.J. ECON. 745,754 (I990) ("With heterogeneous preferences, voters' interests may diverge, creating opportunities for majorities to capture wealth from minorities through majority voting."). Several commentators have noted similar problems regarding the median voter in other property-related contexts as well. See, e.g., Robert C. Ellickson \& Vicki L. BEEn, LAND Use Controls: CASES AND MATERLALS 49 (3d ed. 2005) (pointing out that "a municipality might act not to maximize the aggregate value of land within it but rather, for example, to maximize the wealth of the median homevoter" (citing WiLliaM A. FISCHEL, REgULATORY TAKINGS 255-59 (I995) (reviewing literature on the median-voter model)); Henry Hansmann, Condominium and Cooperative Housing: Transactional Efficiency, Tax Subsidies, and Tenure Choice, 20 J. LEGAL STUD. 25, 34 (I99I) (examining decisionmaking mechanisms of condominiums and cooperatives and concluding "there will be substantial room for outcomes that do not maximize the aggregate surplus of the occupants ... when the preferences of the median member are different from those of the mean"). Aware of the problems with majority voting when preferences are heterogeneous, economists have proposed a variety of other mechanisms for addressing similar collective action problems. See, e.g., DAVID M. KREPS, A COURSE IN MiCROECONOMIC ThEORY 704-I2 (I990) (discussing "pivot mechanisms" as an alternative to majority voting in the context of several farmers deciding whether to build a bridge and how to share its costs because, with majority voting, "some farmers may really want this bridge, and if most farmers don't care that much ... , then the bridge won't be built, even though general social welfare would be improved if it were built," $i d$. at 705). I thank Eric Talley for bringing this example to my attention.
} 
Heller and Hills acknowledge that LADs might become "a curse of majoritarian tyranny" if investment-oriented owners (that is, owners who value their property based solely on its fair market value) were to dominate LADs. ${ }^{6}$ But they maintain that this risk of majoritarian exploitation is "remote" because it is unlikely that "investors who place no special value on their parcels above their market value" would "dominate a particular neighborhood." The possibility of overassembly, however, does not depend on whether a LAD contains a certain percentage of investment-oriented owners. A LAD with a majority of investors is only one among many possible distributions that can lead to an undesirable assembly. Indeed, heterogeneity may result in overassembly even in situations, like the numerical example above, in which the LAD does not include any investment-oriented owners. ${ }^{8}$ In addition, heterogeneity also may result in underassembly, and underassembly, like overassembly, is possible even in a LAD without investment-oriented owners.

To be sure, using eminent domain has costs as well. The government normally does not have perfect information regarding valuations. If it underestimates the owners' valuations or overestimates a developer's valuation, the government may execute an undesirable assembly; conversely, if it overestimates the owners' valuations or underestimates a developer's valuation, the government may fail to execute a desirable assembly. Concerned that just compensation tends to be undercompensatory, owners also may have an excessive incentive to object to condemnations, thereby increasing assembly costs and deterring desirable assemblies. ${ }^{9}$ Moreover, in deciding whether to condemn property, the government sometimes may act for reasons other than maximizing welfare. ${ }^{10}$

Whether LADs are superior to eminent domain thus depends on whether, empirically, the costs of heterogeneity are less than the costs of government misestimation and maleficence. This determination requires knowing, for LADs and eminent domain, the value lost because of socially undesirable assemblies that do occur and socially desirable transfers that do not occur. However, there is no reason to believe

6 Heller \& Hills, supra note I, at I499.

7 Id. at $\mathrm{I}_{502-03}$.

8 In the example above, Owners I, 2, 3, 4, and 5 each value their parcels above fair market value and thus are not merely investors.

9 See Heller \& Hills, supra note I, at $\mathrm{I} 48 \mathrm{I}-82$

10 See Daryl J. Levinson, Making Government Pay: Markets, Politics, and the Allocation of Constitutional Costs, 67 U. CHI. L. REV. 345, 375-77 (2000) (providing an "interest group analysis in the takings context"); see also Abraham Bell \& Gideon Parchomovsky, Givings, I I Y YLE L.J. 547,603 n.255 (200I) ("[P]ublic choice theory disputes the Pigouvian view of government and requires the discipline of the Takings Clause to prevent excess use of the power of eminent domain."). 
a priori that the costs of LADs will necessarily be less than the costs of eminent domain.

\section{ASSEmbly VAlue AND BILAteral MONOPOLY}

Another distinctive feature of LADs is that they allow existing owners to bargain with an assembler over whether or not to sell their neighborhood. In this way, LADs attempt to ensure that transfers are welfare-enhancing — the primary benefit of private assembly. Yet neighborhood bargaining also entails a cost. Specifically, because existing owners will have an incentive to bargain for a share of the project's assembly surplus (that is, for a share of the difference between the value of the parcel as assembled and the value of the parcel's fragmented interests), bargaining may deter assemblies that are socially desirable resulting, once again, in the problem of underassembly.

Developers and other private parties ordinarily use voluntary transactions to assemble land. If holdouts are thought to be problematic, developers can rely on buying agents to circumvent strategic sellers and assemble land secretly. ${ }^{11}$ With secret purchases, existing owners are unaware of the buyer's identity, as well as the nature of the project, and are therefore unable to negotiate over the project's assembly value. ${ }^{12}$ Similarly, when land is taken through eminent domain, condemnees are not entitled to any share of the assembly surplus. ${ }^{13}$ In contrast, to assemble land using a LAD, a developer would be required not only to pay the property's fair market value and the owners' subjective value but also to negotiate over the project's assembly value. These negotiations raise the price of assembling land; and, perhaps more importantly, they may lead to a bilateral monopoly problem.

Assume the developer from our initial example values the land at $\$ 75$ (rather than $\$ 65$ ). The developer would then value the property more than the existing owners $(\$ 75>\$ 70)$. With private assembly through buying agents, the existing owners would be unaware of the larger project and would have no reason to attempt to extract the assembly's surplus. With LADs, however, the existing owners would know the assembler's identity, the assembly's scope, and perhaps even the site's post-assembly use. The owners, as well as the assembler,

11 See generally Daniel B. Kelly, The "Public Use" Requirement in Eminent Domain Law: A Rationale Based on Secret Purchases and Private Influence, 92 CORNELL L. REV. I, I8-33 (2006).

12 See David A. Dana, Reframing Eminent Domain: Unsupported Advocacy, Ambiguous Economics, and the Case for a New Public Use Test, 32 VT. L. REV. I29, I39 (2007) ("[I]n the case of covert assembly, landowners are also denied any of the value that may result from successful assembly because they are unaware of the ongoing assembly efforts.").

13 See United States v. Miller, 3I7 U.S. 369, 375 (1943). 
would therefore have an incentive to capture the entire surplus (that is, $\$ 5$ ). If the parties anticipate that their subsequent negotiations might evaporate any gains from trade, the assembly might not occur. ${ }^{14}$ For example, if a developer believes the costs of negotiating with a LAD will be $\$ 6$, the developer will forgo this assembly opportunity because the transaction costs, $\$ 6$, are greater than the gains from trade, $\$ 5$. Ultimately, this bilateral monopoly problem, or even just the prospect of losing the entire surplus of an assembly, might reduce the incentive for developers to search for and initiate assembly projects. ${ }^{15}$

One might object that a developer could circumvent this bilateral monopoly problem by establishing multiple LADs. Utilizing multiple LADs would only solve the problem, however, if the administrative costs of additional LADs were relatively low. As currently designed, the costs of LADs are significant. ${ }^{16}$ Creating a LAD requires "defining LAD boundaries, establishing a LAD Board, and selecting governing directors." 17 Moreover, "[t]o educate the neighbors about the potential benefits and costs of a LAD, the government would hold a series of hearings in which the private land assembler could make the case for land assembly to the neighbors." 18 Each LAD thus entails additional costs for both the existing owners and the assembler.

Suppose that the costs involved in the creation and implementation of each LAD were $\$ 3, \$ 2$ for the existing owners and $\$ \mathrm{I}$ for the assembler. With a single LAD, the assembly discussed above still would be desirable because the benefits to the assembler, $\$ 74\left(\$ 75_{-}-\$ 1\right)$, would be greater than the costs to the existing owners, $\$ 72(\$ 70+\$ 2)$. With multiple LADs, however, the administrative costs would soon

14 See Thomas W. Merrill, The Economics of Public Use, 72 CORNELL L. REV. 6I, 75 (I986) ("[S]trategic bargaining in a bilateral monopoly situation increases [a] project's transaction costs, and if the transaction costs approach or exceed the project's gains, the [project] may never be built."). Heller and Hills themselves recognize this potential bilateral monopoly problem in two particular applications. See Heller \& Hills, supra note I, at I493-94 (explaining that, if a neighborhood and the government are bilateral monopolists negotiating over a unique site, "[t]he resulting dickering and deception may eat away all of the gains from trade"); id. at 1508 ("[V]oluntary bargains between a LAD composed of the owners of blighted land and the city might fail as a result of the dickering arising from bilateral monopoly.").

15 See Perry Shapiro \& Jonathan Pincus, Efficiency and Equity in the Assemblage of Land for Public Use: The $\mathrm{L}_{2} \mathrm{H}_{2}$ Auction ${ }_{5}$ (Dec. 2007) (unpublished manuscript), available at http://www. economics.adelaide.edu.au/workshops/workshops/2008papers/080407pincus.pdf ("We are skeptical that private developers will step forward with LAD proposals if the hard work of making a proposal is not rewarded by a guaranteed participation in the rewards of the resulting assemblage."); cf. Merrill, supra note $\mathrm{I}_{4}$, at 85 (arguing that "the surplus from eminent domain functions here much as profit does in the market" and that "restitution could eliminate the use of eminent domain altogether").

16 See Heller \& Hills, supra note I, at 1489 (noting the "high administrative costs of creating a LAD")

17 Id.

18 Id. at 1490 . 
dissipate any of the gains from trade. With two LADs, for example, the benefit to the developer, $\$ 73(\$ 75-\$ I(2))$, would be less than the costs to the owners, $\$ 74(\$ 70+\$ 2(2))$. Thus, although multiple LADs might help prevent the bilateral monopoly problem, multiple LADs also would mean higher costs, ${ }^{19}$ and these costs might prevent desirable assemblies. ${ }^{20}$

Of course, private assembly, like eminent domain, has costs. Private transactions may result in underassembly if certain owners are unwilling to sell at any price. ${ }^{21}$ For those transfers that require secrecy, there is also some probability that buying agents might be detected. $^{22}$ The use of buying agents entails certain transaction costs as well. ${ }^{23}$

Whether LADs are superior to private assembly thus depends on whether, empirically, the costs of negotiating over assembly value (including the potential administrative costs of creating multiple LADs), plus the costs of heterogeneity, ${ }^{24}$ are less than the various costs of private assembly. But, just as there is no reason to believe a priori that the costs of LADs will necessarily be lower than the costs of eminent domain, there is no reason to suppose a priori that the costs of LADs will necessarily be lower than the costs of private assembly. ${ }^{25}$

19 See Amnon Lehavi \& Amir N. Licht, Eminent Domain, Inc., Io7 Colum. L. Rev. I704, I728 n.IIO (2007) (noting "the transaction and coordination costs of setting up and operating a multitude of LADs").

20 In this respect, LADs differ from other self-governance mechanisms (such as common interest communities, business improvement districts, and block-level improvement districts) that do not entail the creation of multiple institutions for a single project.

21 See Kelly, supra note II, at 24 n.I33.

$22 I d$. at 30.

23 See Heller \& Hills, supra note I, at 1473.

24 See supra Part I, pp. 8-I2.

25 In my analysis, I assume that private assembly and LADs are mutually exclusive assembly options. However, to minimize assembly costs, developers could employ a sequential strategy of first using private assembly and then initiating a LAD or first initiating a LAD and then using private assembly. Cf. Heller \& Hills, supra note I, at I488 (mentioning the possibility that "a developer will have assembled part of a block" before proposing a LAD's boundaries). The problem with permitting a developer to utilize both private assembly and a LAD is that it increases the possibility of opportunistic behavior. For example, a developer might attempt to acquire a controlling share in a LAD by purchasing individual parcels and then defining a LAD's boundaries to include the parcels it previously had purchased. Similarly, a developer might attempt to obtain a controlling share by defining a LAD's boundaries and then purchasing individual parcels within the LAD it previously had defined. Of course, if a developer engaging in either of these strategies acquired less than fifty percent of the voting rights within the $\mathrm{LAD}$, the developer would still have to bargain with the remaining owners over the project's assembly value. But, if the developer acquired more than fifty percent of the voting rights, the developer itself could approve the assembly (presumably, for some nominal amount). Although various types of jurisdictional or voting rules could be designed to mitigate such problems, the monitoring necessary to minimize this type of opportunism ultimately constitutes an additional cost of LADs. 


\section{AdMINISTRABILITY AND "EXPERTISE"}

Heller and Hills propose LADs as a self-governance mechanism based on majority rule and neighborhood control because they are skeptical about eminent domain reforms that "overestimate the power of expertise." 26 They contend that, when compared with substantive reforms that require courts to redefine "public use" or recalibrate "just compensation," LADs offer a distinct administrability advantage. ${ }^{27}$ Yet the effectiveness of LADs themselves appears to rely to a significant extent on the ability of the courts to resolve relatively complex issues. Indeed, because Heller and Hills would continue to permit condemnations under certain circumstances, the implementation of LADs would require courts to make a number of difficult determinations.

First, courts would be required to distinguish between land that is truly "blighted" and land that is merely "mediocre." Heller and Hills suggest that, although eminent domain would continue to be permitted in blighted areas, "one might require that local governments use LADs rather than eminent domain to remedy 'blight' whenever the jurisdiction defines blight to include neighborhoods of average quality." 28 Certain cases would be relatively straightforward. In Berman v. Parker, ${ }^{29}$ for example, the National Capital Planning Commission declared an area of southwest Washington, D.C. blighted because, among other things, " $57.8 \%$ of the dwellings had outside toilets, $60.3 \%$ had no baths, $29.3 \%$ lacked electricity, $82.2 \%$ had no wash basins or laundry tubs, [and] 83.8\% lacked central heating." ${ }_{30}$ By contrast, in Lakewood, Ohio, dozens of homes were deemed blighted even though, under the relevant criteria (which included the lack of a two-car garage), ninety percent of the city's homes, including the homes of the mayor and entire city council, would have been blighted as well. ${ }^{31}$ It is less apparent whether "dilapidated houses which discourage neighbors from maintaining adjoining property, and perhaps even sound buildings which are crowded too closely together" constitute blight. ${ }^{32}$ However, courts would be required to make such determinations even though "the line separating blighted from regular property is not clear." 33

\footnotetext{
$26 \mathrm{Id}$. at $\mathrm{I} 47 \mathrm{I}$.

27 See id at $\mathrm{I}_{4} 83_{3}-87$.

$28 \mathrm{Id}$. at $\mathrm{I} 509$.

29348 U.S. 26 (1954).

30 Id. at 30 .

31 See 60 Minutes: Eminent Domain (CBS television broadcast Sept. 28, 2003).

32 Note, Public Use as a Limitation on Eminent Domain in Urban Renewal, 68 HaRv. L. REv. I422, I424 (I955).

33 Abraham Bell \& Gideon Parchomovsky, The Uselessness of Public Use, ro6 CoLuM. L. REV. I4I2, I437 (2006); see also Kelly, supra note I I, at 59 ("[D]istinguishing actual blight from asserted blight is a relatively difficult task.").
} 
Courts also would be required to determine whether an assembly site is "unique." Heller and Hills would permit the use of eminent domain for "high-quality land — land that has the quality of being, in some sense, uniquely suited" to the assembler's purposes — but suggest that "LADs be required whenever the assembler can make a credible threat to develop an alternative site." 34 In a town that contained only one hill suitable for a telephone tower, a developer would not have a credible threat to acquire an alternative site. ${ }^{35}$ In contrast, as Heller and Hills point out, General Motors had several sites (besides Poletown) that were credible alternatives for its new factory. ${ }^{36}$ A case like Kelo v. City of New London ${ }^{37}$ is less clear. A successful development anywhere in the city would have improved employment and the tax base. Yet the parcel of land in Fort Trumbull had a number of site-specific features, including its proximity to the waterfront and Pfizer's new research facility, that made it a particularly attractive location. ${ }^{38}$ Once again, courts would have to engage in line-drawing even though uniqueness is, as the authors admit, often a matter of degree. ${ }^{39}$

Finally, courts would be required to decide whether a LAD's condemnation of opt-outs would violate the Public Use Clause. ${ }^{40}$ As noted above, Heller and Hills give dissenting owners the right to opt out but allow a LAD to condemn an opt-out's land using "ordinary eminent domain procedures." 41 However, even under Kelo, such condemnations might be deemed takings for private use. As an initial matter, LAD condemnations might trigger heightened scrutiny because they entail the use of eminent domain "to benefit a particular class of identifiable individuals." ${ }_{42}$ Unlike a taking that benefits an unidentified future developer, a LAD involves the use of eminent domain to benefit a particular private party. Indeed, the assembler itself may have proposed the LAD to city planners. ${ }^{43}$ Moreover, in some cases, the LAD's use of eminent domain may not even involve a "public purpose" such as generating new jobs or bolstering the tax base. The

\footnotetext{
34 Heller \& Hills, supra note I, at I509.

35 See, e.g., Williams v. Hyrum Gibbons \& Sons Co., 602 P.2d 684 (Utah 1979).

36 See Heller \& Hills, supra note $\mathrm{I}$, at $\mathrm{5} 5 \mathrm{\text {Io }}$ (discussing the circumstances surrounding Poletown Neighborhood Council v. City of Detroit, 304 N.W.2d 455 (Mich. I98I)).

37545 U.S. 469 (2005)

38 See id. at $473-75$.

39 See Heller \& Hills, supra note I, at I494 (asking how we define the border between fragmentation and uniqueness, "two concepts that, in reality, bleed into each other").

40 U.S. CONST, amend. V ("[N]or shall private property be taken for public use, without just compensation.").

41 Heller \& Hills, supra note I, at 1496.

42 Kelo, 545 U.S. at 478 (quoting Haw. Hous. Auth. v. Midkiff, 467 U.S. 229,245 (I984)) (internal quotation marks omitted).

43 See Heller \& Hills, supra note I, at I488.
} 
LAD assembler simply may believe that it is a higher-value user of the parcel. Under conventional analysis, such a transfer from $A$ to $B$ merely because $B$ values the property more than $A$ would not constitute a public use. ${ }^{44}$

Implementing LADs would thus require courts to determine whether an assembly site is truly blighted or merely mediocre, whether the site is uniquely suited for a particular purpose, and whether condemnations within LADs actually serve a public purpose. Perhaps these issues will be easier for courts to decide than disputes concerning the appropriate definition of "public use" or the optimal level of "just compensation." But disagreements almost inevitably will arise, and, when they do, courts will be required to apply general legal rules to specific factual circumstances, a result that necessarily entails some degree of "expertise" and not just self-governance.

\section{CONCLUSION}

Despite the above-mentioned concerns, and assuming that LADs can be designed to avoid any potential constitutional pitfalls, there is still an argument that (at least some) state legislatures should consider authorizing LADs. The immediate effect of Kelo was to give states a significant degree of freedom to experiment with various degrees of property rights protection. In a post-Kelo world, certain states continue to permit eminent domain in almost all circumstances; other states prohibit the use of eminent domain for promoting economic development; and still others preclude the use of eminent domain for either promoting economic development or eliminating urban blight. Given this variability in state law, a novel proposal like LADs is certainly worthy of consideration, especially by states concerned with both protecting property rights and facilitating economic development.

44 See Kelo, 545 U.S. at 477 ; Midkiff, 467 U.S. at 245 